\title{
HISTORIA
}

https://doi.org/10.15633/sts.4178

ANNA SUCHECKA

(D) https://orcid.org/0000-0002-0274-9352

Uniwersytet Marii Curie-Skłodowskiej w Lublinie
Studia Sandomierskie

$28(2021)$

\section{KANONIK SANDOMIERSKI MARCIN Z URZĘDOWA I JEGO HERBARZ POLSKI W HISTORIOGRAFII}

\begin{abstract}
Wstęp
Herbarz polski, wydane w 1595 r. wielkie dzieło kanonika sandomierskiej kapituły kolegiackiej Marcina z Urzędowa, było pierwszym oryginalnym polskim zielnikiem ${ }^{1}$. Przyznaje mu się największą wartość wśród wszystkich prac o roślinach wydanych drukiem w Krakowie w XVI w. Ustalenia te są wystarczającym powodem do podjęcia systematycznych badań monograficznych nad dwoma aspektami: życiem sandomierskiego kanonika i wydrukowanym 22 lata po jego śmierci dziełem² Jednak zadanie rekonstrukcji bogatej biografii duchownego oraz jego opus vitae okazuje bardzo trudne ze względu na szerokie spektrum potrzebnej do tego wiedzy. Należy prześledzić dzieje instytucji i wspólnot w historii Kościoła, w ramach których Marcin funkcjonował oraz awansował, zbadania wymaga również jego kariera naukowa w Polsce i za granicą. Rozległe zagadnienie stanowi rekonstrukcja jego warsztatu botanicznego, medycznego i farmaceutycznego, który przygotował go do napisania, jak wyżej wspomniano, pierwszego oryginalnego zielnika w języku polskim. Badania te zostały zaledwie zapoczątkowane, przeszkodę zaś w ich finalizacji, jak się wydaje, stanowi problem interdyscyplinarności, który wynika ze specyfiki badań nad zielnikami. Jest to typ renesansowej książki o charakterze encyklopedii zielarskiej, zwany również herbarzem (od łac. herba - «ziele»), choć herbarzem nazywano również zupełnie inny rodzaj publikacji, który zawierał wizerunki i opisy herbów, czyli znaków osobistych i rodowych.

Zielnik czy też herbarz (jak w tytule dzieła Marcina z Urzędowa) zawiera opisy ziół wraz z podaniem ich leczniczych właściwości, a także opisy wielu innych substancji, produktów i zjawisk. Ważną i wyróżniającą cechą tych książek była ich bogato ilustrowana forma typograficzna przyjmująca wzorce renesansowe, zwłaszcza wspaniałe drzeworyty roślin. Jak widać, w badaniach zielników przydatna okazuje się wiedza z takich dziedzin, jak historia botaniki, farmacji, medycyny oraz innych

1 Marcin z Urzędowa, Herbarz polski, to jest o przyrodzeniu ziót i drzew rozmaitych, Kraków 1595.

2 Z. Bela, O potrzebie badań nad „Herbarzem Polskim” Marcina z Urzędowa, „Archiwum Historii i Filozofii Medycyny" 63 (2000), z. 3-4, s. 86-87.
\end{abstract}


nauk przyrodniczych, dzieje kultury oraz bibliologia historyczna (dzieje druku i typografii), historia sztuki drzeworytniczej, a także informacje językoznawcze w zakresie nomenklatury przyrodniczej. Badania $w$ tych wszystkich dziedzinach wraz z zagadnieniami biografii kanonika Marcina z Urzędowa tworzą materiał bardzo rozproszony, wymagający zebrania i krytycznej oceny. Może on być punktem wyjścia do ujęć wszechstronnie wyczerpujących temat renesansowego fenomenu, jakim był Herbarz polski. Równie interesujące są impulsy zewnętrzne: źródłoznawcze i archiwoznawcze wpływające na poszerzenie historiograficznych informacji budujących biogram duchownego.

\section{Badania nad biografią Marcina z Urzędowa}

Często dopiero fascynująca spuścizna pisarska pociąga za sobą badania biograficzne nad osobą jej autora. Taki mechanizm wystąpił u zarania dziewiętnastowiecznych badań nad Herbarzem polskim. Dziełem tym interesowali się historycy medycyny we wszystkich zaborach ${ }^{3}$, jednak dopiero krakowski pionier historii botaniki, Józef Rostafiński (1850-1928), zrekonstruował zrąb biografii Marcina z Urzędowa i dokonał źródłowej analizy jego zielnika ${ }^{4}$. Posłużyły mu do tego informacje pozyskane $\mathrm{z}$ archiwum uniwersyteckiego, Acta episcopalia $\mathrm{z}$ Archiwum Kurii Krakowskiej oraz wnikliwie przeanalizowane szczegóły biograficzne wtrącone przez samego Marcina do treści zielnika. Poza tym J. Rostafiński zwrócił się do opiekuna biblioteki seminarium sandomierskiego, ks. prof. Ludwika Rocha Piotrowicza ${ }^{5}$, o wypis z akt oficjalatu testamentu Marcina z Urzędowa, który wydał in extenso jako appendix do artykułu o literaturze botanicznej XVI w. ${ }^{6}$ Ustalił w ten sposób pochodzenie autora

3 L. Gąsiorowski, Zbiór wiadomości do historyi sztuki lekarskiej w Polsce od czasów najdawniejszych, aż do najnowszych, t. 1, Poznań 1839, s. 302-305; K.W. Wójcicki, Stare gawędy i obrazy, t. 3, Warszawa 1840, s. 83-105; A. Kremer, Pierwsze zielniki polskie, w: Historya nauk przyrodzonych podtug ustnego wykładu Jerzego Kiuwiera (Couvier), t. 2, Wilno 1854, s. 200-220; J. Bartoszewicz, Czy Marcin Urzędów, czy Marcin z Urzędowa? Pytki historyczno-literackie, cz. 4, „Dziennik Warszawski” (1854), nr 176, s. 182, 184-185; K. Wróblewski, Marcin z Urzędowa i jego zielnik, „Pamiętnik Towarzystwa Lekarskiego" 79 (1883), s. 65-105.

4 J. Rostafiński, Nasza literatura botaniczna XVI wieku, oraz jej autorowie lub ttomacze, rozdz. 9, Marcin z Urzędowa i jego dzieto: Herbarz Polski, „Pamiętnik Akademii Umiejętności w Krakowie. Wydział Matematyczno-Przyrodniczy” 14 (1888), s. 184-207.

5 B. Stanaszek, R. Nowakowski, P. Tylec, Piotrowicz Ludwik Roch, w: Stownik biograficzny księży diecezji sandomierskiej XIX-XX w., t. 3, $M-R$, Sandomierz 2017, s. 167-168.

6 J. Rostafiński, Nasza literatura botaniczna ..., art. cyt., s. 205-207. Ks. Alfons Bułakowski opublikował thumaczenie testamentu Marcina z Urzędowa: zob. A. Bułakowski, Ksiądz Marcin z Urzędowa, kanonik sandomierski, lekarz i botanik z XVI wieku, „Przegląd Katolicki” (1888), nr 34 z 11/23VIII , s. 529-535. Artykuł ten został niedawno przedrukowany: A. Rolla „Miodek”, Ks. Marcin z Urzędowa , lub kiedykolwiek obchodzić może...”, „Głos Ziemi Urzędowskiej” (2020), s. 33-39. 
Herbarza, podał wyczerpujący zestaw informacji dotyczących jego pobytu w Akademii: promocje, przedmioty wykładane, funkcje, a zwłaszcza zbiór wypisów z akt sądu rektorskiego, przed którym późniejszy kanonik stawał w różnych sprawach, co świadczy zresztą o jego porywczym charakterze.

Następnie zrekonstruowano kolejność takich wydarzeń z życia autora Herbarza, jak święcenia kapłańskie, wyjazd do Włoch, powrót do kraju na altarię, a następnie kanonię w Sandomierzu oraz pełnienie funkcji lekarza znanych magnatów, a także proboszcza w Urzędowie i Modliborzycach. J. Rostafiński wyliczył również na podstawie testamentu kolejne procesy dotyczące uposażeń tych parafii oraz kontakty i krąg współpracowników kanonika u schyłku życia. Jak widać, ów badacz botaniki osiągnął doskonałe rezultaty $\mathrm{w}$ dziedzinie historiografii, co doszło do skutku dzięki współpracy z twórcą krakowskiej szkoły historycznej, Józefa Szujskiego.

W uzyskaniu kompletnego biogramu przeszkodził na tym etapie brak dostępu do źródeł sandomierskich przechowywanych w archiwum kapituły i w archiwum miejskim. Po II wojnie światowej wraz z edycją źródeł, porządkowaniem akt i otwieraniem się archiwów na badania historyczne doszło do pierwszych odkryć i uzupełnień biograficznych. Ów trend rozpoczął Henryk Rutkowski, ustaliwszy na podstawie akt miejskich przyrynkowe usytuowanie sandomierskiej kamienicy Marcina oraz odnotowany $w$ testamencie fakt udzielania przez niego pożyczek mieszczanom $^{7}$. Z kolei Feliks Kiryk uzupełnił losy kanonika w pracy poświęconej lekarzom i aptekarzom sandomierskim, szeroko czerpiąc $\mathrm{z}$ akt kapitulnych ${ }^{8}$. Przede wszystkim ustalił fakt pełnienia przez Marcina funkcji proboszcza poza wzmiankowanymi wyżej miejscowościami również w Zaleszanach. Wspomniany badacz na podstawie wielu wzmianek w źródłach kościelnych potwierdził prowadzenie przez kanonika działalności kredytowej pod zastaw nieruchomości, co było przyczyną znacznej jego zamożności, zbudowanej nie tylko na uposażeniu kościelnym i zawodowym lekarza. Dane mieszczan sandomierskich, którym Marcin pożyczał gotówkę, zestawiła Dominika Burdzy, uzupełniając jego biografie o szczegóły dotyczące pełnienia funkcji altarzysty w sandomierskim kościele św. Piotra9. Z tych wzmianek wyrasta nieco inne niż ugruntowane w starszej literaturze oblicze Marcina z Urzędowa jako mieszczanina i finansisty ${ }^{10}$.

Osobno należy omówić gromadzenie wiedzy o krakowskiej karierze uniwersyteckiej, gdyż wymienieni badacze oprócz J. Rostafińskiego niezbyt się tym problemem interesowali. Detale tego aspektu życia duchownego uporządkował autor biogramu Marcina z Urzędowa w Polskim słowniku biograficznym, Leszek Hajdu-

7 H. Rutkowski, Z dziejów Sandomierza w okresie Odrodzenia, w: Studia sandomierskie. Materiaty do dziejów miasta Sandomierza i regionu sandomierskiego, red. T. Wąsowicz, J. Pazdura, Sandomierz 1967, s. 316-318.

8 F. Kiryk, Lekarze i aptekarze sandomierscy z przełomu XVI i XVII stulecia, Sandomierz 1987, s. 17.

9 D. Burdzy, Szesnastowieczny Sandomierz. Kościót i miasto, Kielce 2012, indeks.

10 J. Wiśniewski, Katalog prałatów i kanoników sandomierskich, Radom 1928, s. 201. 
kiewicz ${ }^{11}$. Wiedzę na ten temat znacznie poszerzył Zbigniew Bela, lecz jego artykuł sytuuje się zupełnie poza humanistycznym obiegiem naukowym, gdyż został opublikowany $\mathrm{w}$ czasopiśmie farmaceutycznym ${ }^{12}$. Dopiero zebranie informacji z podstawowych uczelnianych źródeł drukowanych i rękopiśmiennych w postaci biograficznych baz danych środowiska Uniwersytetu Krakowskiego Corpus Academicum Cracoviense na nowo otworzyło możliwości pracy nad karierą akademicką Marcina z Urzędowa. To nowoczesne narzędzie badawcze zbiera wszystkie wzmianki o edukacji i stopniach naukowych oraz pełnionych funkcjach Marcina, co umożliwiło pełną rekonstrukcję jego kariery uniwersyteckiej ${ }^{13}$.

Innymi drogami przebiegały studia nad padewskim wykształceniem Marcina. Pierwszy materiały do historii Polaków w Padwie zebrał Stanisław Windakiewicz, który podał datę promocji doktorskiej sandomierskiego kanonika $(1538)^{14}$. Alicja Zemanek opracowała padewskie inspiracje polskich zielnikarzy, a wśród nich Marcina z Urzędowa ${ }^{15}$. Szczegółowe procedury jego promocji doktorskiej wraz ze składem zespołów egzaminacyjnych wydano w Padwie w 1971 r., lecz dopiero Małgorzata Anna Ciosmak postarała się o ich tłumaczenie i ogłoszenie w polskiej literaturze ${ }^{16}$. O śladach zagranicznej działalności kanonika, a właściwie nabywaniu przez niego obcych dzieł potrzebnych do poszerzania wiedzy świadczą jego zapisy własnościowe na kilku starodrukach ${ }^{17}$. Badań tych nie można uznać za zakończone,

11 L. Hajdukiewicz, Marcin z Urzędowa, w: Polski stownik biograficzny, t. 19, Wrocław 1974, s. 575-577. Warto dodać, że autor tego biogramu doskonale orientował się również w problematyce historii naturalnej, por. L. Hajdukiewicz, Pliniusz w Europie, w: Pliniusz, Historia naturalna, wybór, tł. i kom. I. i T. Zawadzcy, Wrocław-Kraków 1961, s. XLVXLXXVIII.

12 Z. Bela, Uniwersytecka kariera Marcina z Urzędowa, „Farmacja Polska” 58 (2002), nr 24, s. $1135-1146$.

13 Marcin z Urzędowa, syn Szymona (Id: 2019660), w: Corpus Academicum Cracoviense, cac.historia.uj.edu.pl/osoba/2019660_Marcin_z_Urz\%C4\%99dowa_syn_Szymona [dostęp: 11 VIII 2021 r.]. Równolegle trwają prace nad wydawaniem źródeł do dziejów Uniwersytetu Krakowskiego z tego okresu: Metryka, czyli Album Uniwersytetu Krakowskiego z lat 1509-1551. Biblioteka Jagiellońska rkp. 259, wyd. A. Gąsiorowski, T. Jurek, I. Skierska, współpr. R. Grzesik, Warszawa 2010; Najstarsza księga promocji Wydziatu Sztuk Uniwersytetu Krakowskiego z lat 1402-1541, wyd. A. Gąsiorowski, T. Jurek, I. Skierska, Kraków 2011; por. M. Zdanek, Edycje ksiąg urzędowych Uniwersytetu Krakowskiego - dzieło na nowo podjęte, w: Editiones sine fine, red. K. Kopiński, W. Mrozowicz, J. Tandecki, Toruń 2017, s. 67-89.

14 Materyaly do historyi Polaków w Padwie, zebrał S. Windakiewicz, Kraków 1891, s. 14.

15 A. Zemanek, Z dziejów botaniki Renesansu - padewskie inspiracje polskich zielnikarzy, „Kwartalnik Historii Nauki i Techniki” 41 (1996), nr 1, s. 42-43.

16 Acta graduum academicorum Gymnasii Patavini ab anno 1538 ad annum 1550, a cura di E. Martellozzo Forin, t. 3, parte 3, Padova 1971, nr 2446, 2447, 2450; M.A. Ciosmak, 10 stycznia 1538 roku w Padwie, „Głos Ziemi Urzędowskiej” (2008), s. 31-32.

${ }_{17}$ W. Wisłocki, Incunabula typographica Bibliothecae Universitatis Jagellonicae Craco- 
o czym świadczy odkrycie w zasobie biblioteki kanoników regularnych w Krakowie woluminu z odręcznym autografem Marcina. Zawiera on trzy weneckie druki dzieł Arystotelesa, w tym jeden w wydaniu Aldusa Manucjusza, które autor Herbarza zapewne przywiózł z Włoch ${ }^{18}$. Odkrycie ksiąg o takiej proweniencji jest możliwe również w innych bibliotekach, przede wszystkim w księgozbiorach klasztornych. $\mathrm{Na}$ tym należy zakończyć omawianie literatury zawierającej źródłowe dane biograficzne, wprowadzające nowe treści do curriculum vitae Marcina. Oczywiście wiele innych pozycji wzmiankuje o nim lub zawiera skompilowane informacje na temat jego życia. Pomimo wtórności kilka z nich ukazuje życie i działalność kanonika w szerszym, interesującym kontekście ${ }^{19}$.

\section{Badania naukowe Herbarza polskiego}

Niektóre wspomniane prace historiograficzne i biograficzne zawierają dane bibliograficzne i bibliologiczne dotyczące Herbarza polskiego oraz jego treści, lecz dokonania te należy omówić osobno w związku z osiągnięciami dziedzin badawczych stosujących metody adekwatne wobec zielników, jak dzieje botaniki, medycyny i farmacji czy bibliologia historyczna. $\mathrm{W}$ tym przypadku również pierwszeństwo należy przyznać J. Rostafińskiemu, który zbadał źródła i zawartość zielnika Marcina z Urzędowa i uznał go za znaczne osiągnięcie naukowe i pierwszy wkład w geografię roślin ${ }^{20}$. Dokonał nowoczesnego ujęcia porównawczego w zakresie bibliograficznym i ustalił relację Herbarza polskiego do wcześniejszych polskich zielników opartych na piśmiennictwie średniowiecznym ${ }^{21}$. Przedstawił szczegółową analizę bibliologiczną wszystkich elementów zielnika i dokonał oceny właściwości drzewo-

viensis, Cracoviae 1900, s. 527; Katalog inkunabułów Biblioteki Zakładu im. Ossolińskich we Wrocławiu, oprac. A. Kawecka-Gryczowa, Wrocław 1956, s. XVI, 34; Katalog starych druków Biblioteki Zakładu Narodowego im. Ossolińskich. Polonica wieku XVI, oprac. M. Bohonos, Wrocław 1965, s. 27.

18 I. Pietrzkiewicz, Biblioteka kanoników regularnych w Krakowie w XV i XVI wieku, Kraków 2003, s. 85, 118-119; T. Moskal, Książka w kulturze sandomierskiego środowiska kolegiackiego do 1818 roku, Sandomierz 2013, indeks.

19 H. Barycz, Historja Uniwersytetu Jagiellońskiego w epoce humanizmu, Kraków 1935, indeks; M. Surdacki, Edukacja i opieka społeczna w Urzędowie XV-XVIII w., Lublin 2004, indeks; R. Szczygieł, Lokacja miasta na prawie niemieckim i jego dzieje $w$ czasach jagiellońskich, w: Dzieje Urzędowa, red. R. Szczygieł, M. Surdacki, Lublin-Urzędów 2011, indeks; F. Kiryk, F. Leśniak, Mieszkańcy, w: Dzieje Sandomierza, t. 2, XVI-XVIII w., cz. 1, W okresie świetności, red. F. Kiryk, Warszawa 1993, s. 236. Wydawnictwa słownikowe są wtórne i często powielają błędy, np. H. Bukowiecki, Marcin z Urzędowa, w: Słownik biologów polskich, red. S. Feliksiak, Warszawa 1987, s. 355-356; M. Czarnota, Marcin z Urzędowa, w: Stownik biograficzny ziemi kraśnickiej, t. 1, red. J.S. Kamyk Kamieński, M. Surdacki, Kraśnik 2020, s. 178-179.

20 J. Rostafiński, Nasza literatura botaniczna ..., art. cyt., s. 152-207.

21 S. Falimirz, O ziołach i mocy ich, Kraków 1534; H. Spiczyński, O ziołach tutecznych i zamorskich, Kraków 1542; M. Siennik, Herbarz, to iest ziół [...] opisanie, Kraków 1568. 
rytów. Treść zielnika posłużyła J. Rostafińskiemu również do identyfikacji i weryfikacji roślin znanych ze źródeł średniowiecznych ${ }^{22}$.

Po pionierskich publikacjach w późniejszych latach życia systematycznie pogłębiał i ogłaszał badania nie tylko nad treścią Herbarza, ale również nad warsztatem jego autora, budowanym na postawie wyników poszukiwań terenowych ${ }^{23}$. J. Rostafiński rozpoczął również językoznawczy kierunek badań nad nazewnictwem botanicznym w zielnikach, w tym Herbarzu polskim, publikując Stownik polskich imion i rodzajów - do dzisiaj pełniący funkcję polskiego kodeksu nomenklatorycznego ${ }^{24}$. Badacz ogłaszał wyniki na tym polu w czasopismach filologicznych, lecz dzisiaj uważa się je za prace z pogranicza historii botaniki, językoznawstwa i etnobotaniki ${ }^{25}$. Jak widać, badania Rostafińskiego charakteryzowała cecha, którą obecnie określa się jako interdyscyplinarność. Jej stosowanie w praktyce, a zwłaszcza łączenie źródeł i metod stosowanych w obszarze nauk humanistycznych i przyrodniczych, będące koniecznością wobec takiego przedmiotu badawczego jak renesansowy zielnik, omówiono w innym miejscu ${ }^{26}$.

Jednak istotne są również specjalistyczne badania nad historią poszczególnych dziedzin związanych z Herbarzem. Zdobycze nowożytnych dziejów medycyny przyniosły zarys historii okulistyki w świetle zielników. Jego autor, Adam Bednarski, profesor Katedry Okulistyki Uniwersytetu Lwowskiego, wyliczył objawy chorobowe znane Marcinowi z Urzędowa oraz leki roślinne stosowane na choroby oczu ${ }^{27}$. Drugą specjalizacją medyczną, której rys historyczny można było uzupełnić, wykorzystując Herbarz polski, była pediatria. Autorem publikacji na ten temat był również znany lekarz, Bolesław Górnicki, który jednak ograniczył się do kilku cytatów z zielnika dotyczących zdrowia dzieci ${ }^{28}$. Z kolei dyrektor war-

22 J. Rostafiński, Średniowieczna Historya Naturalna. Systematyczne zestawienie roślin, zwierzat, minerałów, oraz wszystkich innego rodzaju leków prostych, używanych w Polsce od XII do XVI w., cz. 1-2, Kraków 1900.

${ }^{23}$ J. Rostafiński, Dioscoride in Polonia, w: Omaggio dell'Academia Polacca di Scienze e Lettere all'Università di Padova nell settimo centenario della sua fondazione, Cracovia 1922, s. 331-341; J. Rostafiński, Pierwszy badacz naukowy Tatr, „Kurjer Warszawski” (1923), nr 163, wyd. wieczorne, s. 4-5.

24 J. Rostafiński, Stownik polskich imion rodzajów oraz wyższych skupień roślin poprzedzony historyczna rozprawa o źródłach, Materyały do Historyi Języka $i$ Dyalektologii Polskiej 1, Kraków 1900. Następnym kamieniem milowym w zakresie terminologii lekarskiej, obejmującym również słownictwo zielnikowe Marcina z Urzędowa, była publikacja Franciszka Giedroycia Polski stownik lekarski, t. 1-2, Warszawa 1933.

25 A. Zemanek, Polskie nazewnictwo botaniczne, w: Józef Rostafiński-botanik i humanista, red. A. Zemanek, Kraków 2000, s. 223.

26 A. Suchecka, Badania interdyscyplinarne nad polskimi zielnikami drukowanymi, „Wschodni Rocznik Humanistyczny" 17 (2020), nr 2, s. 199-224.

27 A. Bednarski, Okulistyka ziolopisów polskich w XVI i na początku XVII wieku, Lwów 1917, s. 16-18.

${ }^{28}$ B. Górnicki, Zarys piśmiennictwa pediatrycznego do roku 1600, „Archiwum Historii i Fi- 
szawskiego Ogrodu Botanicznego, Bolesław Hryniewiecki, umieścił zielnik Marcina w syntezie polskiej botaniki na należnym miejscu ${ }^{29}$. Przed II wojną światową ujawnił się również potencjał Herbarza polskiego w zakresie badań nad dziejami zoologii. Odkryto bowiem, że Marcin z Urzędowa jako pierwszy w świecie ustalił przynależność czerwca polskiego Porphyrophora polonica (dotychczas uważanego za roślinę) do świata zwierzą ${ }^{30}$.

Cechy lecznictwa renesansowego na podstawie herbarza Marcina z Urzędowa przebadano w pełni w latach 1954-1959 w Zakładzie Botaniki Farmaceutycznej Akademii Medycznej w Warszawie. Publikacja wyników tych badań otrzymała drugą nagrodę w konkursie na prace związane z polskim renesansem ogłoszonym w 1954 r. przez Komisję Roku Odrodzenia przy Radzie Głównej Szkolnictwa Wyższego $^{31}$. Zasadniczą jej częścią jest identyfikacja gatunków roślin opisanych przez Marcina z Urzędowa i ułożenie ich według systemu taksonomicznego Richarda Wettsteina. Autorzy zestawili również i zidentyfikowali środki lecznicze pochodzenia mineralnego (według układu Gustava Tschermaka) i zwierzęcego (według systemu zoologicznego).

Autorzy Lecznictwa renesansowego w Polsce na postawie „Herbarza” Marcina $z$ Urzędowa zestawili ponadto i omówili zidentyfikowane lekarstwa roślinne według układu chorób z Herbarza. Warto zaznaczyć, że wspomniane studium zawiera również pogłębioną analizę bibliograficzną zielnika, przedstawienie jego źródeł oraz całego dzieła na tle piśmiennictwa polskiego. Zawarta jest w nim także analiza poglądów Marcina na dokonania innych badaczy, ocena jego wiedzy i metod pracy, a także stosunek do zabobonów. Jest to ostatnie ujęcie monograficzne poświęcone Herbarzowi polskiemu, co nie znaczy, że później nie podejmowano nad nim innych badań. Koncentrowano się zwłaszcza nad analizą i interpretacją treści, języka oraz formy tego dzieła, lecz wyniki ogłaszano w publikacjach odnoszących się do piśmiennictwa zielnikowego ${ }^{32}$ bądź szerszych zagadnień, jak dzieje poszczególnych nauk przyrodniczych i humanistycznych ${ }^{33}$.

lozofii Medycyny" 18 (1939-1945), s. 82-83.

29 B. Hryniewiecki, Précis de l'histoire de la botanique en Pologne, publié par la Société Botanique de Pologne à l'occasion du III-ème Congrès des Botanistes Slaves tenu à Varsovie du 24 au 26 juin 1931, Warszawa 1931, s. 7-8.

30 A.W. Jakubski, Czerwiec polski (Porphyrophora polonica L.). Studjum historyczne ze szczególnym uwzględnieniem roli czerwca w historji kultury, t. 1, Warszawa 1934, s. 397.

31 M. Furmanowa, Z. Michalska, A. Parczewski, I. Zarębska, Lecznictwo renesansowe w Polsce na postawie „Herbarza” Marcina z Urzędowa, „Studia i Materiały z Dziejów Nauki Polskiej” Ser. B (1959), z. 2, s. 233-313.

32 S. Konarska-Zimnicka, Herbaria in 16th and 17th Century Poland: Survey of Sources, w: Human, Health, Environment: Psychosocial Factors and Historical Background, ed. by A. Anczyk, Sosnowiec 2011, s. 161-188.

33 P. Rybicki, Odrodzenie, w: Historia nauki polskiej, red. B. Suchodolski, Wrocław 1970, s. 319. 
Badania nad zielnikami jako źródłem do dziejów roślin uprawnych przedstawił Władysław Ochmański, który podał pełną listę roślin uprawianych w polu i w ogrodzie, występujących we wszystkich renesansowych zielnikach, w tym w Herbarzu Marcina, w liczbie 56 gatunków $^{34}$. Dzieło kanonika sandomierskiego wykorzystano także do badań nad znajomością wiedzy przyrodniczej. Ich wyniki potwierdziły związek między tą wiedzy a medycyną, który w XVI w. zaznaczał się w ziołolecznictwie $^{35}$. Do zielnika odwoływano się również w trakcie badań nad dziejami wybranych roślin, jak np. winorośli ${ }^{36}$. Herbarz obok innych zielników posłużył wspomnianej wyżej A. Zemanek do identyfikacji sposobów wykorzystania dziesięciu roślin z okresu średniowiecza, pozyskanych z krakowskich materiałów archeobotanicznych ${ }^{37}$. Badania nad identyfikacją roślin są kontynuowane ${ }^{38}$. Z kolei materiał zoologiczny opisany w zielniku doczekał się pogłębionych badań Katarzyny Justyniarskiej-Chojak ${ }^{39}$.

Szerszy nurt badawczy zarówno przyrodniczy, jak i humanistyczny zajął się bogato ilustrowaną formą typograficzną przyjmującą wzorce renesansowe. Władysław Szafer, który rozpoczął swoje badania w dwudziestoleciu międzywojennym, w 1964 r. ogłosił w Krakowie zarys historii botaniki, w którym zawarł nowe ustalenia na temat funkcji identyfikacyjnej drzeworytów w zielniku ${ }^{40}$. Barbara Kuźnicka oraz A. Zemanek przy okazji badań nad rolą ilustracji w herbarzach wielokrotnie podkreślały, również na podstawie dzieła Marcina, silny związek czy wręcz harmonię lub jedność nauki i sztuki renesansu ${ }^{41}$.

34 W. Ochmański, Staropolskie herbarze i zielniki jako źródło do dziejów roślin uprawnych, „Studia i Materiały z Dziejów Nauki Polskiej” seria B (1967), z. 13, s. 4-29.

35 T. Bieńkowski, Wiedza przyrodnicza w Polsce w wieku XVI, Wrocław 1985, s. 84, 87-92.

36 M. Kwapieniowa, Początki uprawy winorośli w Polsce, „Materiały Archeologiczne” 1 (1959), s. 365; A. Suchecka, T. Giergiel, Właściwości lecznicze wina i uprawa winorośli wedtug renesansowych zielników, w: Powrót do tradycji winiarskich Ziemi Sandomierskiej. Materiały konferencyjne, red. J. Suszyna, Sandomierz 2014, s. 22-72.

37 A. Zemanek, Wybrane rośliny średniowiecznego Krakowa $w$ polskich zielnikach renesansu, w: Rośliny w życiu codziennym mieszkańców średniowiecznego Krakowa, red. A. Mueller-Bieniek, Kraków 2012, s. 211-242.

38 A. Wróbel, P. Cygan, M. Korzeniowska, Znane i mniej znane rośliny lecznicze z „Herbarza Polski" Marcina z Urzędowa, Kraków 1595, w: Pamiętnik XXII Sympozjum Historii Farmacji. Rośliny w farmacji, Ciechanowiec, 27 kwietnia - 2 maja 2013 r., red. J. Majewski, Poznań 2013, s. 229-242.

${ }^{39}$ K. Justyniarska-Chojak, „O rzeczach żywych ku lekarstwam stużacych” - zwierzęta $w$ polskich poradnikach medycznych z XVI wieku, w: Zwierzęta $w$ historii, literaturze i sztuce Europy, red. S. Konarska-Zimnicka, L. Kostuch, B. Wojciechowska, Kielce 2017, s. 257-274.

40 W. Szafer, Zarys historii botaniki w Krakowie na tle sześciu wieków Uniwersytetu Jagiellońskiego, Kraków 1964, indeks.

41 B. Kuźnicka, Rola artystycznego drzeworytu w rozwoju wiedzy o roślinach leczniczych, w: Przeszłość przyszłości. Księga ofiarowana Bohdanowi Suchodolskiemu, Warszawa 
Ilustracje botaniczne stanowią wyróżniającą cechę edytorską i podstawowe kryterium dla bibliologii kategoryzującej polskie renesansowe zielniki drukowane, ograniczając ten typ książki do pięciu dzieł, wśród których znalazł się Herbarz pol$s k i^{42}$. Drzeworyty polskich zielników, w tym Herbarza, zestawił i wydał zbiór ich reprodukcji Józef Muczkowski³ ${ }^{43}$ Niewiele jest jednak na ten temat badań, artykuł zaś Katarzyny Krzak-Weiss Natura $w$ drewnie wyrzezana. O drzeworytach z polskich zielników drukowanych w XVI stuleciu wystawił jedynie wysoką ocenę cechom kompozycyjnym i typograficznym omawianego starodruku ${ }^{44}$. Pewien wkład do badań nad zielnikiem wniosły studia nad dziejami książki, drukarni i typografii autorstwa Alodii Kaweckiej-Gryczowej, Marii Judy oraz Klaudii Sochy ${ }^{45}$.

Ostatnim znaczniejszym nurtem wypływającym z początkowych kierunków badań jest językoznawstwo botaniczne i medyczne. W ramach opracowania polskiej terminologii lekarskiej powstała analiza leksykologiczna nazw z zakresu anatomii (proste prymarne nazwy nie motywowane, jednowyrazowe nazwy motywowane, nazwy dwuwyrazowe, nazwy wielowyrazowe $)^{46}$. Została ona oparta m.in. na ziel-

1975, s. 77-83; A. Piekiełko-Zemanek, Rola ilustracji $w$ historii botaniki, „Kwartalnik Historii Nauki i Techniki" 31 (1986), nr 2, s. 505-522; A. Zemanek, Marcin z Urzędowa, „Wiadomości Botaniczne” (1997), nr 1, s. 71-72; A. Zemanek, Renaissance Botany and Modern Science, w: Studies in Renaissance Botany, eds. Z. Mirek, A. Zemanek, Polish Botanical Studies. Guidebook Series 20, Kraków 1998, s. 9-47; B. Kuźnicka, The Union of Science and Art in the Renaissance: At the Sources of Modern Botany, w: Studies in Renaissance Botany..., dz. cyt., s. 49-72.

42 Obok zielników S. Falimirza, H. Spiczyńskiego, M. Siennika i S. Syreńskiego. Książka specjalna dawna. Zielnik, w: Encyklopedia wiedzy o książe. Wrocław 1971, k. 1295; Zielnik, w: Encyklopedia książki, t. 2, K-Z, red. A. Żbikowska-Migoń, M. Skalska-Zlat, Wrocław 2017, s. 672-673.

43 J. Muczkowski, Zbiór odcisków drzeworytów w różnych dziełach polskich w XVI i XVII wieku odbitych a teraz w Bibliotece Uniwersytetu Jagiellońskiego zachowanych, Kraków 1849 .

${ }^{44}$ K. Krzak-Weiss, Natura $w$ drewnie wyrzezana. O drzeworytach z polskich zielników drukowanych w XVI stuleciu, w: Obraz natury w kulturze intelektualnej, literackiej $i$ artystycznej doby staropolskiej, red. E. Buszewicz, J. Dąbkowska-Kujko, A. Jakóbczyk-Gola, A. Nowicka-Jeżowa, Warszawa 2020, s. 198-220.

45 A. Kawecka-Gryczowa, Januszowski Jan, w: Drukarze dawnej Polski od XV do XVIII wieku, t. 1, Małopolska, cz. 1, Wiek XV-XVI, red. A. Kawecka-Gryczowa, Wrocław 1983, s. 88; Privilegia typographica Polonorum. Polskie przywileje drukarskie 1493-1793, oprac. i wyd. M. Juda, Lublin 2010, s. 453; M. Juda, Książka medyczna w dawnej Polsce. Zarys problematyki, w: Zastugi oraz dylematy życiowe i zawodowe lekarzy chirurgów $w$ świetle literatury $i$ medycyny, red. nauk. G. Wallner, E. Łoch, Lublin 2011, s. 62-72; K. Socha, Typografia publikacji pochodzacych z drukarń Uniwersytetu Jagiellońskiego 1674-1819, Kraków 2016, indeks.

${ }^{46}$ F. Wysocka, Polska terminologia lekarska do roku 1838. Anatomia, t. 1, Proste prymarne nazwy nie motywowane, Wrocław 1980; t. 2, Jednowyrazowe nazwy motywowane, Kraków 1994; t. 3, Nazwy dwuwyrazowe, Kraków 2007; t. 4, Nazwy wielowyrazowe, Kraków 
nikach, w tym na Herbarzu polskim, uważanym za typ literatury najbardziej reprezentatywny dla początków literatury medycznej. Stanowiła ona również podstawę dla opracowania przez Annę Spólnik nazw polskich roślin do XVIII w. Jej monografia zawiera wykaz i analizę pochodzenia historycznych nazw roślin mający postać słownika. Autorka systematyzuje nazwy zapożyczone z języka czeskiego, ruskiego, niemieckiego, łaciny oraz z innych języków ${ }^{47}$. Ustalenia etymologiczne przestawiono szerzej w wielu artykułach poświęconych leksyce botanicznej ${ }^{48}$.

Można powiedzieć, że kierunki badań nad dziełem Marcina z Urzędowa zostały zapoczątkowane i rozwinięte przez J. Rostafińskiego oraz zespół M. Furmanowej, prowadzono je zaś na tle studiów nad wszystkimi polskimi herbarzami ${ }^{49}$. Historiografia medycyny renesansowej także podąża ścieżkami wytyczonymi w pierwszej połowie XX w. Precyzyjna metodyka zastosowana przez Marcina Warackiego w badaniach dziejów chorób zębów opisanych przez Marcina z Urzędowa przyniosła doskonałe wyniki w postaci rekonstrukcji wiedzy o dawnej dentystyce ${ }^{50}$. Co należy podkreślić, praca ta wyszła spod pióra historyka - w odróżnieniu od lekarzy będących autorami wzmiankowanych wyżej opracowań z zakresu okulistyki i pediatrii. Ostatnia synteza dziejów medycyny polskiej od czasów najdawniejszych do upadku I Rzeczpospolitej zawiera odniesienia do Herbarza polskiego, lecz w tym obszarze wykazuje wiele usterek ${ }^{51}$.

2013. Por. F. Wysocka, Zarys historii polskiej literatury medycznej i piśmiennictwa medycznego do początków XIX wieku, Piotrków Trybunalski 1999.

47 A. Spólnik, Nazwy polskich roślin do XVIII wieku, Wrocław 1990.

48 A. Spólnik, Nazwy polskich roślin leczniczych w źródtach od XVI do XVIII wieku, w: Studia językoznawcze. Streszczenia prac doktorskich, t. 12, Studia konfrontatywne i historia, red. W. Boryś, Wrocław 1988, s. 177-228; A. Spólnik, Zapożyczenia w polskim słownictwie botanicznym w źródłach do wieku XVIII, w: Język - teoria-dydaktyka. Materiały IX Konferencji Młodych Językoznawców-Dydaktyków, red. M. Preyzner, Kielce 1990, s. 191-206; A. Spólnik, Nazwy roślin afrodyzjaków w staropolskich herbarzach, w: Historia leków naturalnych, t. 4, Z historii i etymologii polskich nazw roślin leczniczych, red. B. Kuźnicka, Warszawa 1993, s. 51-59.

49 Starszy stan badań na ogół jest odnotowany w bibliografiach tematycznych: zob. M. Chmielińska, Polska bibliografia zielarstwa za okres od początku XVI wieku do roku 1940, Warszawa 1954; A. Zemanek, Bibliografia botaniki w Uniwersytecie Jagiellońskim (1532-1917), Kraków 1988.

50 M. Waracki, Dentystyka w Rzeczypospolitej XVI-XVIII wieku w świetle zielników i poradników medycznych, w: Wśród córek Eskulapa. Szkice z dziejów medycyny i higieny w Rzeczypospolitej XVI-XVIII wieku, cz. 1, red. A. Karpiński, Warszawa 2009, s. 103-184. Ukazała się też krótka rekapitulacja wiedzy w postaci syntezy: W. Piotrowski, Medycyna polskiego renesansu, Jawor 1995.

51 J. Skalski, Medycyna w Polsce od czasów najdawniejszych do upadku I Rzeczpospolitej, Warszawa 2016, s. 147 i nn. Autor błędnie stawia dzieło De herbarum virtutibus wydane przez Szymona z Łowicza na równi z pozostałymi wydanymi po polsku zielnikami, które bezrefleksyjnie zalicza do nurtu „upowszechniania wiedzy medycznej”, dość kontro- 
Osiągnięcia historiografii nauk medycznych obfitują także w wiele drobnych prac odnoszących się do zaleceń Marcina z Urzędowa, dziejów chorób i epidemii opisanych przez niego oraz stosowania środków leczniczych (w tym alkoholi), a także studiów identyfikujących źródła współczesnych metod leczenia określonych dolegliwości ${ }^{52}$. Zainteresowaniem cieszą się poglądy i porady Marcina dotyczące zdrowia i pielęgnacji kobiet ${ }^{53}$. Niektóre $\mathrm{z}$ tych prac są $\mathrm{w}$ dużym stopniu oparte na treści Herbarza polskiego. Można też zauważyć obecność zielników wśród źródeł takich kształtujących się kierunków badań, jak etnomedycyna ${ }^{54}$.

W innych dziedzinach naukowych spektrum badawcze znacznie się poszerza. Pojawiają się nowe dziedziny, subdyscypliny i specjalizacje rozwijające metody badań pozwalające na szerszą interpretację historyczną i filologiczną zielników, jak również potraktowanie ich jako źródła poznania kultury staropolskiej w wymiarze społecznym

wersyjnie nazywa też Marcina z Urzędowa „najsłynniejszym lekarzem ziemi sandomierskiej”. Z kolei poziom prezentacji treści Herbarza polskiego wynika ze słabej jakości jego omówień w opracowaniach.

${ }_{52}$ I. Arabas, Wybrane rośliny o działaniu uzależniajacym $w$ renesansowych herbarzach polskich, w: Historia leków naturalnych, t. 2, Natura i kultura-wspótzależności w dziejach lekoznawstwa, red. B. Kuźnicka, Warszawa 1989, s. 131-138; A. Kasperowicz, Rośliny panacea renesansowych zielników polskich, w: Historia leków naturalnych, t. 5, Materia pharmaceutica, red. B. Kuźnicka, Warszawa 1999, s. 33-41; M. Gajewska, Epidemia dżumy $w$ Rzeczypospolitej $w$ świetle XVI-XVII-wiecznych traktatów medycznych i zielników. Profilaktyka indywidualna, w: Wśród córek Eskulapa..., dz. cyt., cz. 1, s. 9-50; A. Suchecka, T. Giergiel, Właściwości lecznicze wina..., art. cyt., s. 22-72; K. Frejlich, Morbus Gallicus w Polsce ostatnich Jagiellonów, w: Wśród córek Eskulapa. Szkice z dziejów medycyny $i$ higieny $w$ Rzeczypospolitej XVI-XVIII wieku, cz. 2, red. A. Karpiński, Warszawa 2015, s. 93-142; J. Węglorz, Zdrowie, choroba i lecznictwo w społeczeństwie Rzeczypospolitej XVI-XVIII wieku, Toruń 2015, indeks; K. Justyniarska-Chojak, Alkohol i jego zastosowanie w staropolskiej medycynie ( $w$ świetle poradników medycznych z XVI wieku), w: Jedza, pija, lulki pala. Używki w świetle źródet archeologicznych $i$ historycznych, red. J. Żychlińska, A. Głowacka-Penczyńska, A. Klonder, Bydgoszcz 2016, s. 95-108; A. Odrzywolska-Kidawa, Piwo w kulturze życia codziennego (połowa XVI w.), w: Jedza, pija, lulki pala..., dz. cyt., s. 109-124; J. Ostrowski, B. Rutkowski, Herbal Treatment of the Urinary System Diseases Based on 16th and 17th Century Herbals in Poland, „Giornale Italiano di Nefrologia" 33 (2016), supp. 66, s. 1-7; D. Babis, Leki naturalne stosowane do XVIII w. w leczeniu górnych dróg oddechowych, „Gazeta Farmaceutyczna” 25 (2016), nr 6, s. 26-28.

53 A. Zdziechiewicz, Obraz kobiety $w$ staropolskich popularnych poradnikach medycznych, „Napis” (2003), seria 9, s. 5-30; L. Wdowiak, Piększydła propagowane w polskich herbarzach wydanych w XVI wieku, „Pomeranian Journal of Life Sciences” 63 (2017), nr 3, s. 52-60; A. Bywalec, Medykamenty i środki pielęgnacyjne pochodzenia zwierzęcego stosowane $w$ polskim lecznictwie od XVI do XVIII wieku, w: Zwierzęta $w$ historii..., dz. cyt., s. 275-288.

54 W. Kozlowska, C. Wagner, E. Moore, A. Matkowski, S. Komarnytsky, Botanical Provenance of Traditional Medicines from Carpathian Mountains at the Ukrainian-Polish Border, „Frontiers in Pharmacology” 9 (2018), article 295. 
i materialnym. W ostatnich latach wzrasta liczba studiów nad mentalnością i życiem codziennym, które w mniejszym lub większym stopniu sięgają do zielników.

Do kategorii mentalności odwołuje się praca Anny Odrzywolskiej-Kidawy o kulturze i higienie życia w twórczości Mikołaja Reja, która cytuje zielniki przy szerokim wykorzystaniu Herbarza polskiego ${ }^{55}$. W założeniach i postępowaniu badawczym jest to ujęcie antropologiczne, nakierowane na rekonstrukcję mikrokosmosu ojca literatury polskiej. Rej doskonale znał zioła i ich właściwości. Zalecał ich uprawę i stosowanie, zarówno w lecznictwie, jak i w kuchni. Zielnik posłużył więc autorce do interpretacji opisywanych przez Reja chorób i ich leczenia, jego stosunku do pożywienia oraz do higieny i estetyki życia codziennego. Ten sam model postępowania badawczego jest realizowany nad mało dostrzeganym zagadnieniem, jak praktyki magiczne ${ }^{56}$.

Poza tym zielniki stanowią podstawę badań nad dziejami żywienia i smaku. Wśród wydanych drukiem receptur rozproszonych $\mathrm{w}$ renesansowych zielnikach znalazły się 23 teksty wyjęte z zielnika Marcina ${ }^{57}$. Przy tej okazji zestawiono miary i wagi występujące $w$ tych źródłach, a poza tym aparat wydawniczy wzbogacono o słownik terminów kulinarnych oraz indeks produktów. Równolegle rozwijały się prace nad zdefiniowaniem przepisu kulinarnego jako rozbudowanego dzieła literackiego znajdującego się w zielnikach. W Herbarzu polskim znaleziono 13 tego typu tekstów, które ogłoszono ${ }^{58}$. Interesujące wyniki badań nad zielnikiem Marcina przynoszą również inne badania filologiczne, np. nad obrazem Nowego Świata, który uzyskał dzięki nim zupełnie nową, nietypową optykę ${ }^{59}$.

55 A. Odrzywolska-Kidawa, Mikrokosmos ,człowieka poczciwego” wedtug Mikołaja Reja. Studia z antropologii kultury szlachty polskiej XVI w. Zdrowie - pożywienie - higiena, Częstochowa 2016, indeks; A. Odrzywolska-Kidawa, ,Czym się ma stary leczyć na złe sprawy swoje" - Mikołaj Rej o ziołach w tradycji leczniczej, w: Lek roślinny - historia $i$ współczesność, t. 2, Leki roślinne w terapii od czasów starożytnych po współczesne. Zagadnienia teoretyczne i praktyczne, red. B. Płonka-Syroka, A. Syroka, K. Sudoł, Wrocław 2013, s. 95-110.

56 S. Konarska-Zimnicka, Ziołolecznictwo $w$ wiekach średnich - przykład praktyk medycznych czy magicznych?, w: Medicina magica. Oblicza medycyny niekonwencjonalnej, red. A. Anczyk, Sosnowiec 2011, s. 41-56; A. Odrzywolska-Kidawa, Praktyki magiczne w XVI w. $i$ ich kontekst kulturowy, „Klio. Czasopismo Poświęcone Dziejom Polski i Powszechnym" 53 (2) (2020), s. 107-132.

57 Staropolskie przepisy kulinarne: receptury rozproszone z XVI-XVIII w. Źródła drukowane, wyd. i oprac. J. Dumanowski, D. Dias-Lewandowska, M. Sikorska, Warszawa 2016, s. $56-325$.

58 J. Snoch, Kilka uwag nad przepisem kulinarnym XVI wieku, w: Kuchnia i stót w komunikacji społecznej. Tekst, dyskurs, kultura, red. W. Żarski, T. Piasecki, Wrocław 2017, s. 201-208; J. Snoch, ,Jako pawa upiec”. Tekst kulinarny w renesansowym zielniku polskim, Warszawa 2018, s. 69-136.

59 A. Elbanowski, Obraz Nowego Świata w staropolskiej literaturze botanicznej i przyrodniczo-lekarskiej, „Acta Botanica Silesiaca” 10 (2014), s. 207-234. 
Jak widać, badania nad Herbarzem polskim uprawia się od kilkudziesięciu lat, ale wyłącznie w szerszych kontekstach ${ }^{60}$. W ostatnim czasie jednak drukuje się także publikacje odnoszące się wyłącznie do życia i dzieła kanonika sandomierskiego. Dotyczą porad gospodarczych zawartych w Herbarzu Marcina, ukazując nieoczywistą wartość tego starodruku i inne niż obecne w literaturze oblicze jego autora, któremu bliska była praktyka życia wiejskiego ${ }^{61}$. Drugą dziedziną pobudzającą do studiów nad działalnością Marcina z Urzędowa są dzieje ogrodów, z uwagi na to, że był on właścicielem jedynego w tej części Europy, obok ogrodu Wawrzyńca Scholza we Wrocławiu, ogrodu roślin leczniczych, zrekonstruowanego w 2015 r. w Sandomierzu. Jego zawartość botaniczną tworzą 23 gatunki roślin uprawianych przez kanonika oraz rośliny rodzime, rosnące w Sandomierzu w XVI w., które on sam wymienił w Herbarzu ${ }^{62}$. Wspomniane prace dają nadzieję na rozwój badań nad renesansową osobowością kanonika i jej bogatym dorobkiem, związanym nie tylko z fitoterapią.

\section{Perspektywy badawcze}

Wydaje się, że pomimo wielu ogłaszanych studiów stan badań nie jest zadawalający. Przede wszystkim nie powstała pełna biografia kanonika ani nowoczesna monografia nt. Herbarza polskiego. Nie będzie to możliwe bez kontynuacji badań interdyscyplinarnych, łączenia źródeł i metod stosowanych w obszarze nauk humanistycznych i przyrodniczych ${ }^{63}$. Uwaga ta odnosi się również do pozostałych zielników renesansowych, lecz w porównaniu z nimi dziełem Marcina z Urzędowa zajmuje się najmniejsza liczba badaczy, a nawet istnieją obszary zupełnego braku wiedzy o jego dokonaniach na różnych polach. Wynika to $\mathrm{z}$ faktu prowadzenia przez sandomierskiego kanonika wszechstronnej działalności: duchownego sprawującego różne funkcje kościelne, studiującego gromadzone dzieła przyrodnicze, ale także empirysty i badacza terenowego, skrzętnego mieszczanina powiększającego swój majątek, w końcu lekarza praktykującego wśród mieszczan i bogatych magnatów.

${ }^{60}$ Cezura ta odnosi się do roku ogłoszenia pracy Lecznictwo renesansowe w Polsce na postawie „Herbarza” Marcina z Urzędowa; zob. przyp. 31.

${ }^{61}$ S. Konarska-Zimnicka, Porady gospodarcze w ,Herbarzu polskim” Marcina z Urzędowa, w: Rycerze, wędrowcy, kacerze. Studia z historii średniowiecznej $i$ wczesnonowożytnej Europy Środkowej, red. B. Wojciechowska, W. Kowalski, Kielce 2013, s. 467-477.

62 A. Suchecka, Sandomierski zielnik Marcina z Urzędowa, kanonika kolegiaty Narodzenia Najświętszej Marii Panny, ,Zeszyty Sandomierskie. Biuletyn Towarzystwa Naukowego Sandomierskiego" (2013), nr 35, s. 10-16; A. Suchecka, T. Giergiel, Otwarcie Sandomierskiego Ogrodu Marcina z Urzędowa, „Wiadomości Botaniczne” 59 (2015), nr 3/4, s. 178-185; A. Suchecka, Sandomierski ogród kanonika Marcina z Urzędowa. Przewodnik, Sandomierz 2015; A. Suchecka, T. Giergiel, Podstawy rekonstrukcji sandomierskiego ogrodu Marcina z Urzędowa, w: Botanika - tradycja i nowoczesność. Streszczenia referatów i plakatów 57. Zjazdu Polskiego Towarzystwa Botanicznego, Lublin, 27 czerwca3 lipca 2016, Lublin 2016, s. 175.

63 A. Suchecka, Badania interdyscyplinarne ..., art. cyt., s. 200. 
W odróżnieniu od reszty zielnikarzy Marcin prowadził tę działalność poza stolicą, w Sandomierzu, gdzie znajduje się nieprzebadany do końca zasób źródłowy, lecz również za granicą, choć zapewne archiwa krakowskie również mogą ukrywać niejeden fakt dotyczący kanonika.

Drugim powodem braku szerszych badań jest oryginalność treści Herbarza polskiego na tle zielników wcześniejszych, które były przepisywane, kompilowane i tłumaczone. Trudności te, jak się można domyślać, powodują czasem wyłączanie Marcinowego zielnika $\mathrm{z}$ badań przekrojowych bez podawania powodu jego pominięcia wśród analizowanych źródeł ${ }^{64}$. Badania nad dziełem Marcina z Urzędowa wymagają wiedzy o postępach nauk przyrodniczych w Europie w wymiarze empirycznym. Autor bowiem był prekursorem początkującej dziedziny, jaką jest geografia roślin, i jako pierwszy opisywał rośliny z autopsji. Wymienione problemy powodują pewien zastój w badaniach. Uzupełnienia wymaga zarówno biografia autora zielnika, zawarta tam myśl naukowa, jak i imponująca forma tego starodruku. Choć wspomniane trudności szybko nie będą przezwyciężone, nie powinny być jednak przeszkodą w pogłębianiu badań nad zawartością Herbarza. W tym zakresie badań wymagają na przykład środki lecznicze pochodzenia mineralnego, szata graficzna tego starodruku oraz jego warstwa językowa. Podejmowanie tych przedsięwzięć będzie jednak nieefektywne bez rozeznania w stanie badań historiograficznych i dyscyplin pokrewnych oraz ustalenia przyczyn ich nawarstwiania się. W ostatnich latach otrzymały one kilka nowych obiecujących impulsów.

\section{Bibliografia}

\section{Źródla}

Acta graduum academicorum Gymnasii Patavini ab anno 1538 ad annum 1550, a cura di E. Martellozzo Forin, t. 3, parte 3, Padova 1971.

Falimirz S., O ziołach i mocy ich, Kraków 1534.

Marcin z Urzędowa, Herbarz polski, to jest o przyrodzeniu ziót i drzew rozmaitych, Kraków 1595.

Marcin z Urzędowa, syn Szymona (Id: 2019660), w: Corpus Academicum Cracoviense, cac.historia.uj.edu.pl/osoba/2019660_Marcin_z_Urz\%C4\%99dowa_ syn_Szymona [dostęp: 11 VIII 2021 r.].

Materyały do historyi Polaków w Padwie, zebrał S. Windakiewicz, Kraków 1891.

${ }^{64}$ Na przykład brak odniesień w artykule: J. Ratajczyk, Obraz koguta w szesnastowiecznych zielnikach polskich, „Literatura Ludowa” 57 (2013), nr 1, s. 33-40, choć zielnik kanonika sandomierskiego zawiera opis wykorzystania kapłona: Marcin z Urzędowa, Herbarz polski..., dz. cyt., s. 396-397. 
Metryka, czyli Album Uniwersytetu Krakowskiego z lat 1509-1551. Biblioteka Jagiellońska rkp. 259, wyd. A. Gąsiorowski, T. Jurek, I. Skierska, współpr. R. Grzesik, Warszawa 2010.

Najstarsza księga promocji Wydziatu Sztuk Uniwersytetu Krakowskiego z lat 1402 1541, wyd. A. Gąsiorowski, T. Jurek, I. Skierska, Kraków 2011.

Privilegia typographica Polonorum. Polskie przywileje drukarskie 1493-1793, oprac. i wyd. M. Juda, Lublin 2010.

Siennik M., Herbarz, to iest ziót [...] opisanie, Kraków 1568.

Spiczyński H., O ziołach tutecznych i zamorskich, Kraków 1542.

Syreński S., Zielnik herbarzem z języka łacińskiego zowia, Kraków 1613.

\section{Opracowania}

Arabas I., Wybrane rośliny o działaniu uzależniajacym w renesansowych herbarzach polskich, w: Historia leków naturalnych, t. 2, Natura i kultura-wspólzależności w dziejach lekoznawstwa, red. B. Kuźnicka, Warszawa 1989, s. 131-138.

Babis D., Leki naturalne stosowane do XVIII w. w leczeniu górnych dróg oddechowych, „Gazeta Farmaceutyczna” 25 (2016), nr 6, s. 26-28.

Bartoszewicz J., Czy Marcin Urzędów, czy Marcin z Urzędowa? Pytki historyczno-literackie, cz. 4, „Dziennik Warszawski” (1854), nr 176, s. 182, 184-185.

Barycz H., Historja Uniwersytetu Jagiellońskiego w epoce humanizmu, Kraków 1935.

Bednarski A., Okulistyka ziołopisów polskich w XVI i na początku XVII wieku, Lwów 1917.

Bela Z., O potrzebie badań nad „Herbarzem Polskim” Marcina z Urzędowa, „Archiwum Historii i Filozofii Medycyny" 63 (2000), z. 3-4, s. 86-87.

Bela Z., Uniwersytecka kariera Marcina z Urzędowa, „Farmacja Polska” 58 (2002), nr 24, s. 1135-1146.

Bieńkowski T., Wiedza przyrodnicza w Polsce w wieku XVI, Wrocław 1985.

Bukowiecki H., Marcin z Urzędowa, w: Stownik biologów polskich, red. S. Feliksiak, Warszawa 1987, s. 355-356.

Bułakowski A., Ksiądz Marcin z Urzędowa, kanonik sandomierski, lekarz i botanik z XVI wieku, „Przegląd Katolicki” (1888) nr 34 z 11/23 VIII, s. 529-535.

Burdzy D., Szesnastowieczny Sandomierz. Kościót i miasto, Kielce 2012.

Bywalec A., Medykamenty i środki pielęgnacyjne pochodzenia zwierzęcego stosowane w polskim lecznictwie od XVI do XVIII wieku, w: Zwierzęta w historii, literaturze i sztuce Europy, red. S. Konarska-Zimnicka, L. Kostuch, B. Wojciechowska, Kielce 2017, s. 275-288.

Chmielińska M., Polska bibliografia zielarstwa za okres od początku XVI wieku do roku 1940, Warszawa 1954.

Ciosmak M.A., 10 stycznia 1538 roku w Padwie, „Głos Ziemi Urzędowskiej” (2008), s. 31-32. 
Czarnota M., Marcin z Urzędowa, w: Słownik biograficzny ziemi kraśnickiej, t. 1, red. J.S. Kamyk Kamieński, M. Surdacki, Kraśnik 2020, s. 178-179.

Elbanowski A., Obraz Nowego Świata w staropolskiej literaturze botanicznej i przyrodniczo-lekarskiej, „Acta Botanica Silesiaca” 10 (2014), s. 207-234.

Frejlich K., Morbus Gallicus w Polsce ostatnich Jagiellonów, w: Wśród córek Eskulapa. Szkice z dziejów medycyny i higieny w Rzeczypospolitej XVI-XVIII wieku, cz. 2, red. A. Karpiński, Warszawa 2015, s. 93-142.

Furmanowa M., Michalska Z., Parczewski A., Zarębska I., Lecznictwo renesansowe w Polsce na postawie „Herbarza” Marcina z Urzędowa, „Studia i Materiały z Dziejów Nauki Polskiej” seria B (1959), z. 2, s. 233-313.

Gajewska M., Epidemia dżumy w Rzeczypospolitej w świetle XVI-XVII-wiecznych traktatów medycznych i zielników. Profilaktyka indywidualna, w: Wśród córek Eskulapa. Szkice z dziejów medycyny i higieny w Rzeczypospolitej XVI-XVIII wieku, cz. 1, red. A. Karpiński, Warszawa 2009, s. 9-50.

Gąsiorowski L., Zbiór wiadomości do historyi sztuki lekarskiej w Polsce od czasów najdawniejszych, aż do najnowszych, t. 1, Poznań 1839.

Giedroyć F., Polski stownik lekarski, t. 1-2, Warszawa 1933.

Górnicki B., Zarys piśmiennictwa pediatrycznego do roku 1600, „Archiwum Historii i Filozofii Medycyny" 18 (1939-1945), s. 47-102.

Hajdukiewicz L., Marcin z Urzędowa, w: Polski słownik biograficzny, t. 29, Wrocław 1974, s. 575-577.

Hajdukiewicz L., Pliniusz w Europie, w: Pliniusz, Historia naturalna, wybór, tłum. i kom. I. i T. Zawadzcy, Wrocław-Kraków 1961, s. XLV-XLXXVIII.

Hryniewiecki B., Précis de l'histoire de la botanique en Pologne, publié par la Société Botanique de Pologne à l'occasion du III-ème Congrès des Botanistes Slaves tenu à Varsovie du 24 au 26 juin 1931, Warszawa 1931.

Jakubski A.W., Czerwiec polski (Porphyrophora polonica L.). Studjum historyczne ze szczególnym uwzględnieniem roli czerwca w historji kultury, t. 1, Warszawa 1934.

Juda M., Ksiażka medyczna w dawnej Polsce. Zarys problematyki, w: Zastugi oraz dylematy zyciowe i zawodowe lekarzy chirurgów w świetle literatury i medycyny, red. nauk. G. Wallner, E. Łoch, Lublin 2011, s. 62-72.

Justyniarska-Chojak K., ,, O rzeczach żywych ku lekarstwam stużacych” - zwierzęta w polskich poradnikach medycznych z XVI wieku, w: Zwierzęta w historii, literaturze i sztuce Europy, red. S. Konarska-Zimnicka, L. Kostuch, B. Wojciechowska, Kielce 2017, s. 257-274.

Justyniarska-Chojak K., Alkohol i jego zastosowanie w staropolskiej medycynie (w świetle poradników medycznych z XVI wieku), w: Używki w świetle źródel archeologicznych $i$ historycznych, red. J. Żychlińska, A. Głowacka-Penczyńska, A. Klonder, Bydgoszcz 2016, s. 95-108. 
Kasperowicz A., Rośliny - panacea renesansowych zielników polskich, w: Historia leków naturalnych, t. 5, Materia pharmaceutica, red. B. Kuźnicka, Warszawa 1999, s. 33-41.

Katalog inkunabutów Biblioteki Zakładu im. Ossolinskich we Wrocławiu, oprac. A. Kawecka-Gryczowa, Wrocław 1956.

Katalog starych druków Biblioteki Zakładu Narodowego im. Ossolińskich. Polonica wieku XVI, oprac. M. Bohonos, Wrocław 1965.

Kawecka-Gryczowa A., Januszowski Jan, w: Drukarze dawnej Polski od XV do $X V I I I$ wieku, t. 1, Matopolska, cz. 1, Wiek XV-XVI, red. A. Kawecka-Gryczowa, Wrocław 1983, s. 69-99.

Kiryk F., Lekarze i aptekarze sandomierscy z przetomu XVI i XVII stulecia, Sandomierz 1987.

Kiryk F., Leśniak F., Mieszkańcy, w: Dzieje Sandomierza, t. 2, XVI-XVIII w., cz. 1, W okresie świetności, red. F. Kiryk, Warszawa 1993, s. 187-268.

Konarska-Zimnicka S., Herbaria in 16th and 17th Century Poland: Survey of Sources, w: Human, Health, Environment: Psychosocial Factors and Historical Background, ed. by A. Anczyk, Sosnowiec 2011, s. 161-188.

Konarska-Zimnicka S., Porady gospodarcze w „Herbarzu polskim” Marcina z Urzędowa, w: Rycerze, wędrowcy, kacerze. Studia z historii średniowiecznej $i$ wczesnonowożytnej Europy Środkowej, red. B. Wojciechowska, W. Kowalski, Kielce 2013, s. 467-477.

Konarska-Zimnicka S., Ziołolecznictwo w wiekach średnich - przykład praktyk medycznych czy magicznych?, w: Medicina magica. Oblicza medycyny niekonwencjonalnej, red. A. Anczyk, Sosnowiec 2011, s. 41-56.

Kozlowska W., Wagner C., Moore E., Matkowski A., Komarnytsky S., Botanical Provenance of Traditional Medicines from Carpathian Mountains at the Ukrainian-Polish Border, „Frontiers in Pharmacology” 9 (2018), article 295.

Kremer A., Pierwsze zielniki polskie, w: Historya nauk przyrodzonych podtug ustnego wykładu Jerzego Kiuwiera (Couvier), t. 2, Wilno 1854, s. 200-220.

Krzak-Weiss K., Natura w drewnie wyrzezana. O drzeworytach z polskich zielników drukowanych w XVI stuleciu, w: Obraz natury w kulturze intelektualnej, literackiej $i$ artystycznej doby staropolskiej, red. E. Buszewicz, J. Dąbkowska-Kujko, A. Jakóbczyk-Gola, A. Nowicka-Jeżowa, Warszawa 2020, s. 198-220.

Ksiązka specjalna dawna. Zielnik, w: Encyklopedia wiedzy o książce, Wrocław 1971, k. 1295.

Kuźnicka B., Rola artystycznego drzeworytu w rozwoju wiedzy o roślinach leczniczych, w: Przeszłość przyszłości. Księga ofiarowana Bohdanowi Suchodolskie$m u$, Warszawa 1975, s. 77-83.

Kuźnicka B., The Union of Science and Art in the Renaissance: At the Sources of Modern Botany, w: Studies in Renaissance Botany, eds. Z. Mirek, A. Zemanek, Polish Botanical Studies. Guidebook Series 20, Kraków 1998, s. 49-72. 
Kwapieniowa M., Początki uprawy winorośli w Polsce, „Materiały Archeologiczne” 1 (1959), s. 353-399.

Moskal T., Książka w kulturze sandomierskiego środowiska kolegiackiego do 1818 roku, Sandomierz 2013.

Muczkowski J., Zbiór odcisków drzeworytów w różnych dziełach polskich w XVI i XVII wieku odbitych a teraz w Bibliotece Uniwersytetu Jagiellońskiego zachowanych, Kraków 1849.

Ochmański W., Staropolskie herbarze i zielniki jako źródło do dziejów roślin uprawnych, „Studia i Materiały z Dziejów Nauki Polskiej” seria B (1967), z. 13, s. 4-29.

Odrzywolska-Kidawa A., , Czym się ma stary leczyć na złe sprawy swoje” - Mikołaj Rej o ziołach $w$ tradycji leczniczej, w: Lek roślinny - historia i współczesność, t. 2, Leki roślinne w terapii od czasów starożytnych po wspótczesne. Zagadnienia teoretyczne i praktyczne, red. B. Płonka-Syroka, A. Syroka, K. Sudoł, Wrocław 2013, s. 95-110.

Odrzywolska-Kidawa A., Mikrokosmos ,człowieka poczciwego” wedtug Mikołaja Reja. Studia z antropologii kultury szlachty polskiej XVI w. Zdrowie - pożywienie - higiena, Częstochowa 2016.

Odrzywolska-Kidawa A., Piwo w kulturze życia codziennego (połowa XVI w.), w: Jedza, pija, lulki pala. Używki w świetle źródet archeologicznych $i$ historycznych. Kulturowe aspekty korzystania z używek na przestrzeni dziejów, red. J. Żychlińska, A. Głowacka-Penczyńska, A. Klonder, t. 1, Bydgoszcz 2016, s. 109-124.

Odrzywolska-Kidawa A., Praktyki magiczne w XVI w. i ich kontekst kulturowy, „Klio. Czasopismo Poświęcone Dziejom Polski i Powszechnym” 53 (2) (2020), s. $107-132$.

Ostrowski J., Rutkowski B., Herbal Treatment of the Urinary System Diseases Based on 16th and 17th Century Herbals in Poland, „Giornale Italiano di Nefrologia” 33 (2016), supp. 66, s. 1-7.

Piekiełko-Zemanek A., Rola ilustracji w historii botaniki, „Kwartalnik Historii Nauki i Techniki" 31 (1986), nr 2, s. 505-522.

Pietrzkiewicz I., Biblioteka kanoników regularnych w Krakowie w XV i XVI wieku, Kraków 2003.

Piotrowski W., Medycyna polskiego renesansu, Jawor 1995.

Ratajczyk J., Obraz koguta w szesnastowiecznych zielnikach polskich, „Literatura Ludowa" 57 (2013), nr 1, s. 33-40.

Rolla „Miodek” A., Ks. Marcin z Urzędowa „lub kiedykolwiek obchodzić może...”, „Głos Ziemi Urzędowskiej” (2020), s. 33-39.

Rostafiński J., Dioscoride in Polonia, w: Omaggio dell 'Academia Polacca di Scienze e Lettere all'Università di Padova nell settimo centenario della sua fondazione, Cracovia 1922, s. 329-342. 
Rostafiński J., Nasza literatura botaniczna XVI wieku, oraz jej autorowie lub tłomacze, rozdz. 9, Marcin z Urzędowa i jego dzieło: Herbarz Polski, „Pamiętnik Akademii Umiejętności w Krakowie. Wydział Matematyczno-Przyrodniczy” 14 (1888), s. 152-207.

Rostafiński J., Pierwszy badacz naukowy Tatr, „Kurjer Warszawski” (1923), nr 163, wyd. wieczorne, s. 4-5.

Rostafiński J., Stownik polskich imion rodzajów oraz wyższych skupień roślin poprzedzony historyczna rozprawa o źródłach, Materyały do Historyi Języka i Dyalektologii Polskiej 1, Kraków 1900.

Rostafiński J., Średniowieczna Historya Naturalna. Systematyczne zestawienie roślin, zwierzą, minerałów, oraz wszystkich innego rodzaju leków prostych, używanych w Polsce od XII do XVI w., cz. 1-2, Kraków 1900.

Rutkowski H., Z dziejów Sandomierza w okresie Odrodzenia, w: Studia sandomierskie. Materiaty do dziejów miasta Sandomierza i regionu sandomierskiego, red. T. Wąsowicz, J. Pazdura, Sandomierz 1967, s. 287-338.

Rybicki P., Odrodzenie, w: Historia nauki polskiej, red. B. Suchodolski, Wrocław 1970, s. 197-436.

Skalski J., Medycyna w Polsce od czasów najdawniejszych do upadku I Rzeczpospolitej, Warszawa 2016.

Snoch J., „Jako pawa upiec”. Tekst kulinarny $w$ renesansowym zielniku polskim, Warszawa 2018.

Snoch J., Kilka uwag nad przepisem kulinarnym XVI wieku, w: Kuchnia i stót w komunikacji społecznej. Tekst, dyskurs, kultura, red. W. Żarski, T. Piasecki, Wrocław 2017, s. 201-208.

Socha K., Typografia publikacji pochodzacych z drukarń Uniwersytetu Jagiellońskiego 1674-1819, Kraków 2016.

Spólnik A., Nazwy polskich roślin do XVIII wieku, Wrocław 1990.

Spólnik A., Nazwy polskich roślin leczniczych w źródłach od XVI do XVIII wieku, w: Studia językoznawcze. Streszczenia prac doktorskich, t. 12, Studia konfrontatywne i historia, red. W. Boryś, Wrocław 1988, s. 177-228.

Spólnik A., Nazwy roślin afrodyzjaków w staropolskich herbarzach, w: Historia leków naturalnych, t. 4, Z historii i etymologii polskich nazw roślin leczniczych, red. B. Kuźnicka, Warszawa 1993, s. 51-59.

Spólnik A., Zapożyczenia w polskim słownictwie botanicznym w źródtach do wieku XVIII, w: Język - teoria - dydaktyka. Materiaty IX Konferencji Młodych Językoznawców-Dydaktyków, red. M. Preyzner, Kielce 1990, s. 191-206.

Stanaszek B., Nowakowski R., Tylec P., Piotrowicz Ludwik Roch, w: Stownik biograficzny księży diecezji sandomierskiej XIX-XX w., t. 3, $M-R$, Sandomierz 2017, s. $167-168$. 
Staropolskie przepisy kulinarne: receptury rozproszone z XVI-XVIII w. Źródta drukowane, wyd. i oprac. J. Dumanowski, D. Dias-Lewandowska, M. Sikorska, Warszawa 2016.

Suchecka A., Badania interdyscyplinarne nad polskimi zielnikami drukowanymi, „Wschodni Rocznik Humanistyczny” 17 (2020), nr 2, s. 199-224.

Suchecka A., Giergiel T., Otwarcie Sandomierskiego Ogrodu Marcina z Urzędowa, „Wiadomości Botaniczne” 59 (2015), nr 3/4, s. 178-185.

Suchecka A., Giergiel T., Podstawy rekonstrukcji sandomierskiego ogrodu Marcina z Urzędowa, w: Botanika - tradycja i nowoczesność. Streszczenia referatów i plakatów 57. Zjazdu Polskiego Towarzystwa Botanicznego, Lublin, 27 czerwca - 3 lipca 2016, Lublin 2016, s. 175.

Suchecka A., Giergiel T., Wtaściwości lecznicze wina i uprawa winorośli wedtug renesansowych zielników, w: Powrót do tradycji winiarskich Ziemi Sandomierskiej. Materiaty konferencyjne, red. J. Suszyna, Sandomierz 2014, s. 22-72.

Suchecka A., Sandomierski ogród kanonika Marcina z Urzędowa. Przewodnik, Sandomierz 2015.

Suchecka A., Sandomierski zielnik Marcina z Urzędowa, kanonika kolegiaty Narodzenia Najświętszej Marii Panny, „Zeszyty Sandomierskie. Biuletyn Towarzystwa Naukowego Sandomierskiego" (2013), nr 35, s. 10-16.

Surdacki M., Edukacja i opieka społeczna w Urzędowie XV-XVIII w., Lublin 2004.

Szafer W., Zarys historii botaniki w Krakowie na tle sześciu wieków Uniwersytetu Jagiellońskiego, Kraków 1964.

Szczygieł R., Lokacja miasta na prawie niemieckim i jego dzieje w czasach jagiellońskich, w: Dzieje Urzędowa, red. R. Szczygieł, M. Surdacki, Lublin-Urzędów 2011, s. 55-100.

Waracki M., Dentystyka w Rzeczypospolitej XVI-XVIII wieku w świetle zielników i poradników medycznych, w: Wśród córek Eskulapa. Szkice z dziejów medycyny $i$ higieny w Rzeczypospolitej XVI-XVIII wieku, cz. 1, red. A. Karpiński, Warszawa 2009, s. 103-184.

Wdowiak L., Piększydla propagowane w polskich herbarzach wydanych $w$ XVI wie$k u$, „Pomeranian Journal of Life Sciences” 63 (2017), nr 3, s. 52-60.

Węglorz J., Zdrowie, choroba i lecznictwo w społeczeństwie Rzeczypospolitej XVIXVIII wieku, Torun 2015.

Wisłocki W., Incunabula typographica Bibliothecae Universitatis Jagellonicae Cracoviensis, Cracoviae 1900.

Wiśniewski J., Katalog prałatów i kanoników sandomierskich, Radom 1928.

Wójcicki K.W., Stare gawędy i obrazy, t. 3, Warszawa 1840.

Wróbel A., Cygan P., Korzeniowska M., Znane i mniej znane rośliny lecznicze $z$ „Herbarza Polski” Marcina z Urzędowa, Kraków 1595, w: Pamiętnik XXII 
Sympozjum Historii Farmacji. Rośliny w farmacji, Ciechanowiec, 27 kwietnia 2 maja 2013 r., red. J. Majewski, Poznań 2013, s. 229-242.

Wróblewski K., Marcin z Urzędowa i jego zielnik, „Pamiętnik Towarzystwa Lekarskiego" (79) 1883, s. 65-105.

Wysocka F., Polska terminologia lekarska do roku 1838. Anatomia, t. 1, Proste prymarne nazwy nie motywowane, Wrocław 1980.

Wysocka F., Polska terminologia lekarska do roku 1838. Anatomia, t. 2, Jednowyrazowe nazwy motywowane, Kraków 1994.

Wysocka F., Polska terminologia lekarska do roku 1838. Anatomia, t. 3, Nazwy dwuwyrazowe, Kraków 2007.

Wysocka F., Polska terminologia lekarska do roku 1838. Anatomia, t. 4, Nazwy wielowyrazowe, Kraków 2013.

Wysocka F., Zarys historii polskiej literatury medycznej i piśmiennictwa medycznego do początków XIX wieku, Piotrków Trybunalski 1999.

Zdanek M., Edycje ksiag urzędowych Uniwersytetu Krakowskiego - dzieło na nowo podjęte, w: Editiones sine fine, red. K. Kopiński, W. Mrozowicz, J. Tandecki, Torun 2017, s. 67-89.

Zdziechiewicz A., Obraz kobiety w staropolskich popularnych poradnikach medycznych „Napis” (2003), seria 9, s. 5-30.

Zemanek A., Bibliografia botaniki w Uniwersytecie Jagiellońskim (1532-1917), Kraków 1988.

Zemanek A., Historia botaniki i innych nauk, w: Józef Rostafiński - botanik i humanista, red. A. Zemanek, Kraków 2000, s. 181-200.

Zemanek A., Marcin z Urzędowa, „Wiadomości Botaniczne” (1997), nr 1, s. 71-72.

Zemanek A., Polskie nazewnictwo botaniczne, w: Józef Rostafiński - botanik i humanista, red. A. Zemanek, Kraków 2000, s. 213-224.

Zemanek A., Renaissance Botany and Modern Science, w: Studies in Renaissance Botany, eds. Z. Mirek, A. Zemanek, Polish Botanical Studies. Guidebook Series 20, Kraków 1998, s. 9-47.

Zemanek A., Wybrane rośliny średniowiecznego Krakowa w polskich zielnikach renesansu, w: Rośliny w życiu codziennym mieszkańców średniowiecznego Krakowa, red. A. Mueller-Bieniek, Kraków 2012, s. 211-242.

Zemanek A., Z dziejów botaniki renesansu - padewskie inspiracje polskich zielnika$r z y$, „Kwartalnik Historii Nauki i Techniki” 41 (1996), nr 1, s. 31-58.

Zielnik, w: Encyklopedia ksiażki, t. 2, K-Z, red. A. Żbikowska-Migoń, M. Skalska-Zlat, Wrocław 2017, s. 672-673. 


\section{Streszczenie}

Wydany w 1595 r. Herbarz polski autorstwa kanonika sandomierskiego Marcina z Urzędowa był pierwszym oryginalnym zielnikiem napisanym po polsku. Wśród wszystkich prac o roślinach wydanych drukiem w Krakowie w XVI w. przyznaje mu się wartość największą. Badania nad biografią Marcina z Urzędowa i treścią zielnika prowadzi się już od prawie dwóch wieków w obrębie różnych nauk: historii botaniki, farmacji, medycyny, dziejów kultury czy bibliologii historycznej, a także językoznawstwa $\mathrm{w}$ zakresie nomenklatury przyrodniczej. Pomimo nawarstwiania się informacji faktograficznych na temat dzieła Marcina z Urzędowa stan wiedzy jest ciągle niezadowalający ze względu na rozproszenie źródeł. Celem artykułu jest przedstawienie i analiza stanu badań, ich słabości oraz niekwestionowanych osiągnięć, co może być punktem wyjścia do ujęcia monograficznego zielnika i pełnej biografii duchownego.

Słowa kluczowe: zielniki drukowane, historia nauk przyrodniczych, historia historiografii, Herbarz polski

\section{The Canon of Sandomierz, Marcin of Urzędów, and His Polish Herbal in Historiography}

\section{Summary}

The Polish Herbal, published in 1595 by the canon of Sandomierz, Marcin of Urzędów, was the first original Polish herbarium. It is given the greatest value among all works on plants published in Krakow in the 16th century. Research on the biography of Marcin of Urzędów and the herbarium content has been going on for almost two centuries within various sciences: history of botany, pharmacy, medicine, history of culture, or historical bibliology, as well as linguistics in the field of nature nomenclature. Despite the accumulation of factual information about the work of Marcin of Urzędów, the state of knowledge is still unsatisfactory due to the dispersion of sources. The aim of the article is to present and analyze the state of research, its weaknesses and unquestionable achievements, which may be the starting point for a monographic approach to the herbarium and a full biography of the clergyman.

Keywords: printed herbaria, history of natural sciences, history of historiography, Polish Herbal 